Magyar Honvédség Parancsnoksága, Kiképzési Csoportfönökség

\title{
A Covid-19 vírus okozta fertőzés fizikai aktivitásra gyakorolt hatása és a sportoláshoz való visszatérés szempontjai
}

\author{
Dr. Eleki Zoltán ezredes, PhD
}

Kulcsszavak: Long-Covid, pandémia, rehabilitációs, fizikai felkészülés, fizikai kondicionálás

A Covid-19 vírus okozta pandémia az egész világon komoly kihívást jelent az élet minden területén. A tanulmány írásakor az igazolt fertőzöttek száma a világon meghaladta a 142 milliós, Magyarországon a 750 ezres számot. Figyelembe véve, hogy a fertőzöttek száma függ az elvégzett tesztek számától, valószínüsíthető, hogy a valós számok ennél még magasabbak.

A gyógyultak számának növekedésével egyre pontosabb képet kapunk arról, hogy a fertőzés akut szakaszának átvészelésével nem minden beteg számára érnek véget a megpróbáltatások, ugyanis számos szervrendszernél jelentkezhetnek elhúzódó, akár több hónapig is tartó tünetek, amelyek arra utalnak, hogy a szervezet még nem nyerte vissza erejét. A Long-Covid Szindróma (LCS) elnevezésü jelenség leggyakrabban a szív-vérkeringést, a légzést, a csont-, izület- és izomrendszert, valamint az emésztőrendszert érinti.

Emellett a betegség súlyosságának függvényében a fizikai teljesítöképesség is jelentős deficitet szenvedhet. Azonban óvatosságra int az a tény, hogy az LCS azokat a szervrendszereket érinti elsösorban, amelyek a mozgásos tevékenységek, így a sportolás során is igénybevételnek vannak kitéve. Amennyiben ezek a szervrendszerek még azelött kapnak nagyobb terhelést, hogy visszanyerték volna egészségüket, az könnyen rosszulléthez és akár maradandó egészségkárosodáshoz vezethet.

A Magyar Honvédség katonái szintén nagy számban esnek át a fertőzésen, így várhatóan az LCS-sel kapcsolatos kockázatok is érintik az állományt. A katonák esetében kiemelt hangsúlyt kap a fizikai felkészïltség kérdése, amit az évente ismétlődő kötelező fizikai felmérés is igazol, ezért mind az egyén, mind az elöljáró számára fontos, hogy a gyógyultak minél elöbb visszanyerjék 
kondíciójukat. Sok múlik azonban a fizikai terhelés helyes adagolásán, a pontos időzítésen és a kellő mértékü fokozatosságon, az idő elötti túlterhelés elkerüilésén.

A sportolás, a mindennapi fizikai aktivitás elősegíti a betegségekkel szembeni ellenállóképesség fenntartását. Figyelembe véve, hogy a Covid-19 fertőzés esetében a legnagyobb kockázati tényező az elhízás, a magas vérnyomás és a cukorbetegség, a mindennapi testmozgáshoz való visszatérés fontossága nem lehet kérdés. Jelen publikáció célja annak feltérképezése, hogy milyen tünetek várhatóak LCS esetén, és ezek figyelembevételével hogyan lehet biztosítani a fokozatos, biztonságos visszatérést a betegség előtti aktivitási szinthez.

\section{A Covid-19 fizikai aktivitást befolyásoló hatása a szervezetre}

A Covid-19 betegség szinte az egész szervezetet érintő lefolyású betegség. Leginkább a szív-vérkeringésre, a légzőrendszerre, a csont-izomrendszerre, a vérre és az emésztörendszerre fejti ki hatását, de emellett az idegrendszerre, a lelki egészségre és a bőr egészségére is hatással van [5]. Lefolyásának súlyossága az alábbi szempontok alapján kategorizálható:

1. A betegség tüneteit nem tapasztaló fertőzött páciens.

2. Tüneteket tapasztaló, a betegséget otthoni izolációban átvészelő páciens.

3. Kórházi kezelésre szoruló személy.

4. Gépi lélegeztetésre szoruló beteg [6].

A kórházi kezelésre szoruló betegek esetében számítani kell a hosszabb rehabilitációs időszakra [7]. A felépülés során figyelembe veendö, hogy mely szervrendszereket érintette leginkább a betegség.

\section{Szív-vérkeringési rendszer}

Több, a szívet érintő komplikációval lehet számolni Covid-19 esetén, mint az aritmia, a miokarditisz és az akut mio- kardiális betegségek [8]. Addig, amíg a rendszeres testmozgás a szív-vérkeringés egészségét pozitívan befolyásolja, a komplikációk fennállásakor a testmozgás akár potenciális okozója is lehet egy végzetes aritmiának [9].

$\mathrm{Az}$ Országos Sportegészségügyi Intézet (OSEI) 2020. október 28-i AKTUALIZÁLT állásfoglalása a COVID-19 fertözött sportolók sportba való visszatérésének kérdésében [10] címü dokumentuma a keringési, légzőrendszeri és központi idegrendszeri szövődményeket emeli ki, amelyek a leginkább befolyásolhatják a sportoló visszatérését. Ezek közül is a szövődményes szívizomgyulladással foglalkozik komolyabban, amelynek következménye szívritmuszavar és akár hirtelen szívleállás is lehet.

A sportolók egészségének megvédése érdekében a sportorvosok, csapatorvosok, válogatott keretorvosok feladatának tekinti a fertőzésen átesett sportolók támogatását, felügyeletét, egyfajta prevenciós tevékenységet, a sportba történő biztonságos, optimális idejű és ütemü visszatérés meghatározását. Ennek érdekében vizsgálni kell az erőnléti-, állóképességi-, proprioceptív képességeket szükséges támogatni ezek visszaszerzé- 
sét a fizikai terhelés megfelelő programjával, sport-dietetikai és sport-pszichológiai módszerekkel.

\section{A kialakított protokoll szerint:}

- Tünetmentes és enyhe tünetes (24 órán belül lezajló tünetek) esetben: 2 hét fizikai kímélet, a versenyszerü sporttevékenység mellőzése mellett. Az első pozitív PCR tesztet vagy az első tünetmentes napot követő három hét után adható meg a sportorvosi engedély a sportoló egyéni egészségi állapotától függően.

- Elhúzódó tünetes (több napon át tartó tünetek vagy kardiális vagy pulmonológiai érintettség) esetben: $\mathrm{Az}$ egyéni állapottól és a tünetektől függően 2-4 hét pihenő. A sportorvosi engedély az első pozitív PCR tesztet vagy az első tünetes napot követően leghamarabb 4-6 héttel adható meg.

- Igazolt szívizomgyulladás vagy szívburokgyulladás esetén: a sportolót 6 hónapra tiltják el a versenyzéstől.

A sportba való teljes visszatérésig mindhárom esetben javasolt a fokozatosság betartása és a pulzuskontroll alkalmazása.

Felnőtt sportolók esetében indokolt a komplex kardiológiai vizsgálat (nyugalmi EKG, szívultrahang, laborvizsgálat, troponin szint meghatározás), amelyet a pihenőidő és a hatósági karantén lejártát követő 1-3. héten szükséges elvégezni. Terheléses EKG vizsgálatot csak normál troponin szint esetén javasolnak.

Kóros eltérések vagy elhúzódó panaszok esetén koronária $\mathrm{CT}$, szív $\mathrm{MR}$, Holter vizsgálat válhatnak szükségessé.

\section{Légzörendszer}

A Covid-19 leggyakoribb tünete a láz és a köhögés, a legsúlyosabb szövődménye pedig a tüdőgyulladás. Miközben a be- tegek többsége az 5-7. napon gyógyul, a 7-14. nap között megnő a veszélye a légzési elégtelenség kialakulásának, ami akár lélegeztetőgépes kezelést is igényelhet.

Az ENSZ Egészségügyi Világszervezete szerint a gyógyulás ideje a légzöszervi tünetek megjelenésétől számítva általában két hét, de a súlyosabb és kritikus esetekben ez akár 3-6 hetet is igénybe vehet. Fiatalabb betegek gyakran minden szövődmény nélkül gyógyulnak, azonban a súlyosabb fertözésen átesett és az idősebb személyek esetében döntő kérdés, hogy mikor és hogyan térhetnek vissza a mindennapi fizikai aktivitáshoz [11].

A Lancet Respiratory Medicine-ben megjelent ajánlás 10 nap nyugalmat javasol a tünetek megjelenésétől számítva és még hét napot a tünetek megszünése után, de természetesen ez nem alkalmazható a súlyos légzőszervi tüneteket produkáló betegek esetében [12]. Nem találtható adat arra vonatkozóan, hogy akik túlélték az akut respirációs distressz szindrómát (ARDS), mennyi idő alatt gyógyultak fel teljesen. Egy 2003-ban Herridge és mtsa-i által végzett vizsgálatból megállapítható, hogy hat hónap kellett ahhoz, hogy a tüdő volumen és a spirometriás értékek normálisak legyenek, és a vizsgált személyek 6\%-ánál az artériás oxigén szaturáció értéke 12 hónap után is $88 \%$ alatt maradt [13]. Fentiek alapján a súlyos légzési szövődmények esetén a betegek sportoláshoz való visszatérését figyelemmel kell kísérnie szakorvosnak, illetve a szükséges klinikai vizsgálatoknak.

\section{Csont-izomrendszer}

A Covid-19 betegséggel összefüggésben a csontok, az ízületi porc, az ízületi tok, a vázizomzat és a simaizomzat érintett 
[14]. A betegek leggyakrabban a myalgia, továbbá az arthralgia tüneteit tapasztalják. Az izomban jelentkező fájdalmakról, gyengeségröl, illetve merevségről a betegek 15\%-a számolt be, és egyéntől függöen pár naptól két hét időtartamig szűnt meg, amit segített a melegítés, a hütés, a sportkrémek használata és a nyújtó gyakorlatok. Az intenzív gyakorlatokat azonban ilyenkor kerülni kell. Az izom fáradékonysága és gyengesége azonban még több hétig jelentkezhet [15].

Összességében elmondható az is, hogy a csont-izomrendszer szempontjából a sporthoz való visszatérést nagyban meghatározzák a tünetek, illetve azok elmúlása. Akiknél fennállnak a tünetek, azok kerüljék az intenzív sporttevékenységet, és ha már nem tapasztalják azokat, akkor kezdjék meg a fokozatos visszatérést a normál fizikai aktivitáshoz. Fel kell hívni a figyelmet arra, hogy aki átesik a Covid-19 betegségen és semmilyen mozgásszervi tünetet nem észlel, annak is ajánlott a visszatérést alacsony intenzitású mozgással kezdeni legalább egy hét időtartamban. A betegség alatti inaktivitás, az edzés hiánya és maga a fertőzés is okozója lehet a mozgásszervi sérüléseknek, ha valaki hirtelen, nagy terhelésnek teszi ki a szervezetét [16].

\section{Hematológiai rendszer}

A Covid-19 betegek között megfigyelhető a vérrögképződési hajlam és ebből adódóan a trombózis veszélyének növekedése. A kórházban kezelt betegek között leginkább a mélyvénás trombózis és a tüdőembólia előfordulása növekedett. A nagyerek elzáródása és a szívizom károsodása szintén előfordult [17].

A sportoláshoz való visszatérés során figyelembe kell venni a vérrögképződés veszélyét [18], ugyanakkor Virchow szerint a trombózis veszélyét három tényező növeli leginkább: ezek a vérrögképződési hajlam, a pangást előidéző mozdulatlanság és az érfal sérülése, illetve nem megfelelö állapota. Ezért a mozdulatlanság és a hosszan tartó utazás rizikófaktorai a trombózisnak. Feltételezések szerint a légzőszervek és a szív kímélése érdekében ugyan a testgyakorlás nem feltétlen ajánlott az akut tüneteket mutató betegek számára, az alacsony intenzitású testmozgás azáltal, hogy a vérrögképződést előidéző faktorokat gyengíti, a tünetmentes és enyhe tüneteket mutató betegek számára kifejezetten ajánlottak [19].

\section{Emésztőrendszer}

A betegeknél nagyobb számban fordulnak elő emésztőszervi tünetek, például hányás, émelygés, étvágytalanság, szag-, ízvesztés és hasmenés. A sporttevékenység szempontjából ez azért fontos, mert a megfelelő folyadék- és táplálékbevitelt befolyásolhatják az emésztőszervi problémák, ami kihatással lehet a bőr, a csontok, az izmok egészségére, valamint az endokrin rendszer müködésére. A folyadék- és kalóriabevitelt ajánlott kontrollálni, megtervezni a betegség akut szakaszában és a sportoláshoz való visszatérés után egyaránt [20].

\section{Idegrendszeri hatások}

A SARS-CoV-2 vírus a sejtek felületén található ACE2 (angiotensin-converting enzyme 2) receptoron keresztül jut be az emberi testbe, elsősorban a légutakon keresztül, de eléri a gerincvelőt is, így feltételezhető, hogy az idegrendszer sebezhetősége jelentős a fertőzés során [21]. Egy Kínában végzett retrospektív vizsgálat szerint a Covid19-en átesett betegek esetében az idegrendszeri szimptómákat három kategóriába sorolták: 
1. A központi idegrendszert érintő tünetek és betegségek, úgymint fejfájás $(13,1 \%)$, szédülés $(16,8 \%)$, eszméletvesztés $(7,5 \%)$, akut agyi keringési történés $(2,8 \%)$ és epilepszia $(0,5 \%)$.

2. A környéki idegrendszert érintő szimptómák, mint az ízlelésvesztés $(5,6 \%)$, szaglásvesztés $(5,1 \%)$ és neuralgia $(2,3 \%)$.

3. Az izomban és csontozatban jelentkező problémák (10,7\%) [22].

\section{Pszichológiai tünetek}

A korábbi CoV által okozott járványok alkalmával több esetben megfigyelhető volt a mentális egészség romlása, amit az érzelmi stressz, a szorongás, a depresszió, a félelem, továbbá a megbélyegzés váltott ki, és egyaránt érintette a betegeket, az egészségügyben dolgozókat, illetve a hozzátartozókat [23]. A SARS vírus okozta járvány után egy évvel 5-44\% szenvedett a mentális egészség romlásától, beleértve a szorongást, depressziót, pszichózist és a PTSD-t. Az okok között szerepelt az életveszély átélése, a családtagok féltése, illetve a mások megfertőzésétől való félelem. A MERS vírus okozta járvány után 12 , illetve 18 hónappal a betegek 27\%-a, illetve $17 \%$-a szenvedett depresszióban, 42\%-a, illetve 27\%-a pedig PTSD-ben [24].

\section{Hogyan ajánlott visszatérni a nagyobb intenzitású sportoláshoz?}

\section{A sportoláshoz való visszatérés szempontjai}

A 2003-ban lezajlott SARS-CoV-1 vírus okozta járvány idején a betegségen átesett páciensek normál fizikai aktivitáshoz történő visszatérésének utánkövetése alapján levont következtetések jó kiinduló alapot szolgáltathatnak a Covid-19 fertőzésen átesett betegek esetében is. Hui és mtsa-i 110 gyógyult személyt tanulmányoztak
6 hónapon keresztül. Hat hónap után a vizsgált egyének fizikai teljesítőképessége és egészségi állapota egyértelműen elmaradt a normál populáció értékeitől. 30\%-nál tapasztaltak eltéréseket a mellkasi röntgenfelvételeken, 15,5\% esetében pedig egyértelmü eltérések mutatkoztak a légzőfelület vonatkozásában. Ezzel öszszefüggésben a tüdő és az izomzat működésében figyeltek meg elégtelenségeket, illetve jellemző volt az izomgyengeség, valamint fáradékonyság [25].

A fentiek alapján ajánlott a Covid-19 fertőzésen átesett betegek 3-6 hónapig történő utógondozása, illetve utánkövetése a fizikai aktivitás tekintetében, függetlenül a betegség lefolyásától. A visszatérés első időszakában érdemes alkalmazni az 50/30/20/10 rehabilitációs szabályt az első négy hét alatt, de szükség esetén tovább is. A szabály lényege, hogy az első héten a fizikai terhelés szintjét a megszokott szint 50\%-ával csökkentett mértékben kell meghatározni. Amennyiben a hét során nem tapasztalható roszszullét, fájdalom vagy bármi olyan jel, ami arra utal, hogy a szervezet még nincs készen a nagyobb megerőltetésre, akkor a következő héten elég a megszokott szint csökkentése 30\%-kal. A következö hetekben pedig hasonlóan 20\%-kal, majd 10\%kal, végül elérhető a teljes terhelés. Természetesen a betegség súlyosságától és az egyén fizikai állapotától függően szükséges lehet a heti tervezés módosítása és akár hónapokat is igénybe vehet, amíg valaki eléri a normál állapotot. Ebben a folyamatban nagyon fontos az egyén tájékoztatása, felvilágosítása arról, hogy milyen tünetek észlelése ad okot a nagyobb óvatosságra, illetve, hogy miképpp kerülhető el a korai túlzott terhelés [26].

A sportolás során a terhelés adagolása mellett néhány általános óvintézkedést is be kell tartani. Fontos a testhőmérsék- 
let ellenőrzése edzés előtt, a sportruházat napi mosása, az alapos és fokozatos bemelegités, illetve az, hogy az izomerösítő gyakorlatok elözzék meg a kardiogyakorlatokat, végül pedig fontos a levezetés a magasabb intenzitású gyakorlatok után. Szintén szükséges lehet a gyakorlatok közötti, illetve az edzések közötti pihenőidő növelése [27]. Ügyelni kell a terhelés adagolására is. A mérsékelt fizikai aktivitás elősegíti az egészséges immunválaszt fertőzések esetén [28], ugyanakkor az inaktivitás az inzulin rezisztencia mértékének növekedéséhez vezethet [29].

Sportolóknál, bizonyos tünetek esetén jól alkalmazható az úgynevezett „neck check” kontroll vagyis az edzésre alkalmasak a sportolók, ha csak a nyak felett szenvednek bizonyos szimptómáktól, úgymint orrdugulás, tüsszentés, viszont tartózkodni kell az edzéstől láz, köhögés és nehézlégzés észlelésekor.

\section{Miért ajánlott a fizikai aktivitás?}

Megismerve a Covid-19 fertőzést követő szimptómákat és a nem kellő időben, illetve mértékkel végzett testmozgás veszélyeit, felmerülhet a kérdés, hogy nem lenne-e biztonságosabb egyszerüen kivárni a teljes gyógyulást, mielőtt a szervezetet elkezdenénk visszaszoktatni a megszokott fizikai aktivitáshoz. Az egyértelmü válasz az, hogy nem lenne biztonságosabb, sőt kevésbé járulna hozzá az egészség visszanyeréséhez és megőrzéséhez. Milyen indokok támasztják alá ezt az állítást?

A Covid-19 fertőzéssel kapcsolatos kockázatelemzés kimutatta, hogy a betegség lefolyásának súlyossága összefügg az elhízással, valamint az elhízás következményeivel, mint a magas vérnyomás és a kettes típusú cukorbetegség, az életkorral, illetve a fizikai aktivitás mértékével [30].

Minden fertözésen átesett személy számára elengedhetetlen, hogy a pilla- natnyi állapotához igazított testgyakorlást végezzen naponta 30-60 perc idötartamban, ezzel elkezdve és fenntartva a fizikai aktivitást, ugyanakkor a csúcsforma elérésének nem most van itt az ideje. A fertőzöttek, főleg súlyos lefolyású betegség után, gyakran szembesülnek olyan szervi károsodással, illetve gyengeséggel, ami gátolja a sportforma gyors visszaszerzését. Még a legedzettebb személyek számára is több hetet vehet igénybe, hogy visszanyerjék a megszokott fizikai állapotukat.

A megfontolt, fokozatos és rendszeres (napi 30-60 perc) testmozgás stimulálja az immunsejtek termelődését, növeli a betegségekkel szembeni ellenállóképességet, csökkenti az akut légúti betegségek és a halálozások számát. Ugyanakkor a nem megszokott magas intenzitású edzés olyan fiziológiai stresszt okozhat, ami az immunrendszer diszfunkciójához vezethet, ami növeli az akut légúti betegségek kockázatát [31].

\section{Hogyan kezdjük újra a sportolást?}

Néhány általános jótanács a sportolást újrakezdőknek:

- A katonák esetében minden igazolt fertözött 30 napra felmentést kap fizikai terhelés alól, ezután orvosi vizsgálaton vesz részt, amit szükség esetén további szakorvosi vizsgálatok egészíthetnek ki. Ha minden rendben van, akkor meg lehet kezdeni a fokozatos visszatérést a testmozgáshoz. Ezeket a lépéseket ajánlott mindenkinek betartani.

- Kezdetben, már a 30 napos felmentési időszakban is, illetve folytatásként ajánlott fenntartani egy mérsékelt fizikai aktivitást, ami heti $150-300$ perc sétával kezdődjön.

- A testmozgást ajánlott szabadban végezni, kihasználva a természet eröi- 
nek jótékony hatását, illetve csökkentve a fertőzésveszélyt.

- Törekedni kell a helyes életmód fenntartására, ezzel összefüggésben az egészséges testsúly elérésére, illetve fenntartására.

- Súlyosabb lefolyású betegségek esetén hosszabb ideig kell tartózkodni a kimerítő gyakorlatoktól.

- Mindenki olyan testmozgást válasszon, amit érdekesnek, élvezetesnek tart.

- A már ismertetett 50/30/20/10 szabály követése támasz lehet a terhelések adagolásához.

- Ügyeljünk a megfelelő folyadékbevitelre és táplálkozásra.

- Ha légzésünkben vagy szívmüködésünkben szokatlan jeleket észlelünk, akkor csökkenteni kell a terhelést, szükség esetén orvoshoz kell fordulni. Ilyen lehet az indokolatlan nehézlégzés, légszomj, fulladás, a pulzusszám indokolatlan növekedése, a megszokottól lassabb pulzusmegnyugvási idő, a hirtelen nagy szívdobbanás (extraszisztolé) vagy a mellkasi fájdalom.

- Alkalmazzuk a helyes edzésintenzitás beállításához, illetve a szívmüködés ellenőrzéséhez a pulzuskontrollt, amelyről később még lesz szó. Szintén hasznos lehet a teljes felgyógyulásig a vér oxigénszintjének időnkénti ellenőrzése pulzoximéterrel.

- Minden edzés előtt alaposan be kell melegíteni, fokozatosan növelve a vérkeringés és a légzés müködését, nyújtó és erősítő hatású gyakorlatokkal az izmok, ízületek bemelegedését, a lágy szövetek bemozgatását, rugalmasságuk növelését.

- Az edzések végén, illetve edzés közben a megterhelö gyakorlatok után biztosítani kell a szervezet fokozatos megnyugvását levezető gyakorlatok alkalmazásával.

\section{Általános javaslatok állóképességi edzésekhez}

Az állóképesség a fáradással szembeni ellenállást, türőképességet jelent, amely a keringési és légzőrendszer, az anyagcsere folyamatok és az idegrendszer összehangolt müködésén alapul. Az alap-állóképesség a tartós, közepes intenzitású, általában ciklikus mozgások hosszabb ideig történő fenntartásának feltétele. Ilyen például a gyaloglás, futás, kerékpározás, evezés, úszás.

Az állóképességet az izommüködést biztosító anyagcsere folyamatok szerint is lehet kategorizálni. Ennek alapján a hosszan tartó, alacsony intenzitású, oxigénellátottság szempontjából kedvezőbb izomtevékenység fenntartásában az aerob állóképesség, míg a nagy intenzitású, az izmok oxigénhiányos körülmények közötti működésének fenntartásában az anaerob állóképesség játszik szerepet.

A kényszerpihenő utáni visszatéréskor először az aerob állóképességet fejlesztő gyakorlatokat kell alkalmazni, amelyek kezdetben hosszú sétákat, majd meneteket jelentenek, amelyekbe fokozatosan be lehet illeszteni rövidebb, majd hosszabb futószakaszokat, végül elérve a folyamatos futás képességét. Ez után lehet a futás hosszát és intenzitását tovább növelni.

$\mathrm{Az}$ anaerob állóképességet fejlesztő gyakorlatokat, vagyis a nagy intenzitású, gyors iramú futásokat akkor szabad csak alkalmazni, amikor már a közepes intenzitású futás során nem észlelhetők szokatlan tünetek, fájdalmak. Ez a módszer természetesen kerékpározás, evezés, úszás és más ciklikus mozgásoknál is jól alkalmazható.

$\mathrm{Az}$ intenzitás szintjének meghatározásában segítséget jelent a szívfrekvencia vagyis a pulzusérték figyelemmel kísérése, mivel a szív percenkénti összehúzódásá- 
nak száma megmutatja, hogy milyen intenzitási zónában edzünk éppen. Abban is segít a pulzuskontroll, hogy meghatározzuk a szükséges pihenőidő mértékét.

\section{Az intenzitási zónák lehetnek:}

- Egészségvédelmi zóna: 50-60\%-os terhelés

- Zsírégető zóna: 60-70\%-os terhelés

- Aerob zóna: 70-80\%-os terhelés

- Anaerob zóna: 80-90\%-os terhelés

- Maximális terhelési zóna: 90-100\%os terhelés

Ma már sokan használnak olyan órákat és egyéb eszközöket, amelyekkel a pulzusszám jól mérhetö, de ha nem áll ilyen rendelkezésre, akkor egy karóra vagy egy mobiltelefon segítségével és a szívverés nyakon vagy csuklón történő kitapintásával is meghatározható a szívfrekvencia.

A pulzuskontroll alkalmazásával az orvos által javasolt nyugalmi időszak után - ajánlott olyan terhelést választani, melynek során a pulzusszám nem haladja meg a 100-at. Ha egy hét alatt nem tapasztalunk rosszullétet, fájdalmat, akkor ez a pulzusérték növelhető 110-120-ra. Az ezt követő hetekben érdemes a Karvonen-képletet alkalmazni az intenzitási zóna meghatározásához.

A Karvonen-képlet lényege az alábbi lépésekben foglalható össze [32]:

- Maximális pulzus meghatározása: 220 - életkor (pl. 220-40=180).

- Pulzustartalék meghatározása: maximális pulzus - nyugalmi pulzus (pl. 180-70=110).

- Edzéspulzus meghatározása: nyugalmi pulzus + pulzustartalék $\mathrm{x}$ intenzitási zóna (pl. 70+110 x 80\% = $70+77$ $=147$ ).

Az 50/30/20/10 rehabilitációs szabály alkalmazásával meghatározható az a cél pulzusérték, amit az edzések során meg kell közelíteni, illetve jelentősen nem szabad túllépni. Mivel betegségből felépülő személyekről van szó, ezért az aerob intenzitás vagy az alatti zónát célszerü választani. Az alábbi példában a fenti 77 bpm pulzustartalékot választva (a könnyebb számolás érdekében 80-ra kerekítve), feltételezve, hogy az egyes szakaszokban nem tapasztal problémát, az alábbiak szerint növelhető az edzések célpulzus értéke:

- 1. hét: könnyed séta, majd hosszabb séták.

- 2. hét: hosszabb séták, a pulzus 100 bpm alatti értéken mozog.

- 3. hét: $50 \%$-os rehabilitációs korlát: $70+80 \times 50 \%=110 \mathrm{bpm}$.

- 4. hét: $30 \%-o s$ rehabilitációs korlát: $70+80 \times 70 \%=126 \mathrm{bpm}$.

- 5. hét: $20 \%$-os rehabilitációs korlát: $70+80 \times 80 \%=134 \mathrm{bpm}$.

- 6. hét: $10 \%$-os rehabilitációs korlát: $70+80 \times 90 \%=142 \mathrm{bpm}$.

- 7. hét: $0 \%-o s$ rehabilitációs korlát: $70+80 \times 100 \%=150 \mathrm{bpm}$.

\section{Általános javaslatok erősítő edzéshez}

Az erősítő hatású gyakorlatok során a vázizomzat munkája áll a középpontban, de az ízületek, az idegrendszer, a légzőrendszer és a szív-vérkeringési rendszer is érintett. A Covid-19 betegség ezeket a szervrendszereket kivétel nélkül érinti, ezért itt is szükséges a kellő óvatosság. A többhetes pihenő önmagában is kedvezőtlenül hat az izomzat állapotára, a vírus ezt a hatást tovább erősíti. Az akut fertőzési szakasz után jellemző az izomzat általános gyengesége, fáradékonysága, sérülékenysége, fájdalma.

Az erősítő edzések jellemzője, hogy az izomzat ellenállással szemben dolgozik, ami lehet valamilyen külső súly vagy maga a gyakorlatozó teste (saját súlyos edzések). 
A terhelés nagyságát az ellenállás nagysága, az ismétlésszám és a pihenőidő adja meg. A sporthoz való visszatérés időszakában kezdetben az ellenállást az izom maximális erőkifejtő képességének az 50-60\%-án, az ismétlésszámot 4-6 darabban, a sorozatokat 3-4 darabban, a pihenőidőt legalább 30-60 másodpercben kell meghatározni. A terhelés fokozását elöször a sorozatszám, majd az ismétlésszám növelésével lehet elkezdeni, az ellenállás nagyságát nem célszerü növelni. Később, ha már 12-16 ismétlést és 6-8 sorozatot végre tudunk hajtani, akkor lehet növelni az ellenállást.

Minden edzés során alaposan be kell melegíteni. A bemelegítés során nagy hangsúlyt kell fektetni a nyugalomban lévő, „hideg” izmok bemozgatására, rugalmasságuk biztosítására, bemelegítésére, az ízületek fokozatos kimozgatására. Legalább ilyen fontos az edzések végén a levezetés, a terhelésnek kitett izmok nyújtása, lazítása, az ízületek átmozgatása.

\section{További ajánlások a sportoláshoz történő biztonságos visszatérés elősegítésére}

Nagyon fontos a betegek tájékoztatása arról, hogy a betegség akut szakasza után is elöfordulhatnak tünetek, amiket komolyan kell venni. Lehet, hogy elég a fizikai terhelési szint csökkentése, de az is elöfordulhat, hogy a tünetekkel azonnal orvoshoz kell fordulni. A Magyar Honvédség állománya számára is szükséges biztosítani a csapatorvosokon és a sportszakembereken keresztül, illetve más belső kommunikációs csatornákon azt a tudást, aminek a birtokában a katonák megfelelően tudják tervezni az egészségük visszaszerzéséhez, illetve megörzéséhez szükséges tevékenységet.

A katonákkal meg kell értetni, hogy saját érdekük a fizikai aktivitáshoz való vissza- térés, mert az inaktív életmód nem segíti a felépülésüket, és védtelenek maradnak egy későbbi betegséggel szemben.

$\mathrm{Az}$ előbb említett szakembereket fel kell készíteni arra, hogy megfelelően tudják segíteni a betegségen átesett személyeket a sporthoz való visszatérésben.

Át kell gondolni, hogy hogyan lehet motiválni az érintetteket a testmozgásra. Felvilágosítással, sportfoglalkozásokkal, könnyített versenyekkel, törődéssel be lehet vonni őket az erőfeszítésekbe. Mérlegelni kell: a fizikai alkalmassági követelmények pozitívan vagy negatívan befolyásolják-e a felkészülésüket. A megfelelési kényszer nem vezet-e oda, hogy hirtelen, nagy terhelésnek teszik ki magukat, mert úgy érzik, hogy kevés idejük van a felkészülésre. Nem szerencsésebb-e megfelelő időt biztosítani a felkészülésre, a kötelező felmérések helyett tájékoztató jellegü felmérések szervezésével? Ennek létjogosultságát támasztja alá az LCS-sel kapcsolatban eddig összegyüjtött nemzetközi és hazai tapasztalat, ami azt mutatja, hogy egy olyan tünetegyüttessel állunk szemben, aminek a kiismerése több időt igényel. Mivel sem idő, sem anyagi forrás nem áll rendelkezésre ahhoz, hogy minden katonánál elvégezzék a felmérések elött az OSEI által a versenysportolóknál alkalmazott vizsgálatokat, meg kell adni az érintetteknek, hogy visszanyerjék régi formájukat. Ebben segítheti őket a megfelelő felvilágosítás, a felkészült és elérhető szakemberek, valamint a támogató foglalkozások.

\section{Irodalom}

[1] https://www.worldometers.info/coronavirus/

[2] Goyal, P.: Clinical characteristics of COVID19 in New York City. 2372-2374. https://doi. org/10.1056/NEJMc2010419

[3] Denay, K.: ACSM Call to Action Statement: COVID-19 Considerations for Sports and Physical Activity. https://journals.lww.com/ 
acsm-csmr/fulltext/2020/08000/acsm_call_ to_action_statement_covid_19.8.aspx

[4] O’Hearn, M.: Coronavirus Disease 2019 Hospitalizations Attributable to Cardiometabolic Conditions in the United States: A Comparative Risk Assessment Analysis. https:// www.ahajournals.org/doi/full/10.1161/ JAHA.120.019259

[5] Wadman, M.: How does coronavirus kill? Clinicians trace a ferocious rampage through the body, from brain to toes:1502-1503. https://www.sciencemag.org/news/2020/04/ how-does-coronavirus-kill-clinicians-traceferocious-rampage-through-body-brain-toes

[6] National Institute for Health and Care Excellence: Rehabilitation after critical illness in adults. https://www.nice.org.uk/guidance/ qs158/resources/rehabilitation-after-criticalillness-in-adults-pdf-75545546693317

[7] Barker-Davies, R.: The Stanford Hall consensus statement for post-COVID-19 rehabilitation. https://bjsm.bmj.com/content/54/ $16 / 949$

[8] Guzik, T. J.: COVID-19 and the cardiovascular system: implications for risk assessment, diagnosis, and treatment options. https://doi.org/10.1093/cvr/cvaa106

[9] Baggish, A.: The resurgence of sport in the wake of COVID-19: cardiac considerations in competitive athletes. https://www.ncbi. nlm.nih.gov/pmc/articles/PMC7513253/

[10] Huang, C.: Clinical features of patients infected with 2019 novel coronavirus in Wuhan, China 497-506. https://doi.org/10.1016/ S0140-6736(20)30183-5

[11] World Health Organization. Report of the WHO-China joint mission on coronavirus disease 2019 (COVID-19). https://www. who.int/docs/default-source/coronaviruse/ who-china-joint-mission-on-covid-19-finalreport.pdf.

[12] Hull, J. H.: Respiratory health in athletes: facing the COVID-19 challenge, 557-558. https://www.thelancet.com/journals/lanres/ article/PIIS2213-2600(20)30175-2/fulltext

[13] Herridge, M. S.: One-year outcomes in survivors of the acute respiratory distress syndrome, 683-693. https://www.researchgate. net/publication/10894122_One-Year_ Outcomes_in_Survivors_of_the_Acute_ Respiratory_Distress_Syndrome

[14] Disser, N. P.: Musculoskeletal consequences of COVID-19. https://journals.lww.com/ jbjsjournal/Fulltext/2020/07150/Muscu loskeletal_Consequences_of_COVID_19. 1.aspx
[15] Guan, W. J.: Clinical characteristics of coronavirus disease 2019 in China, 1708-1720. https://doi.org/10.1056/NEJMoa2002032

[16] Barker-Davies, R.: The Stanford Hall consensus statement for post-COVID-19 rehabilitation. https://bjsm.bmj.com/content/54/ $16 / 949$

[17] Helms, J.: High risk of thrombosis in patients with severe SARS-CoV-2 infection: a multicenter prospective cohort study, 1089-1098. https://doi.org/10.1007/s00134-020-06062-x

[18] Antithrombotic therapy in patients with COVID-19. National Institutes of Health. https://www.covid19treatmentguidelines. nih.gov/antithrombotic-therapy/

[19] Helms, J.: High risk of thrombosis in patients with severe SARS-CoV-2 infection: a multicenter prospective cohort study, 1089-1098. https://doi.org/10.1007/s00134-020-06062-x.

[20] Cholankeril, G.: High prevalence of concurrent gastrointestinal manifestations in patients with SARSCoV-2. https://doi.org/ 10.1053/j.gastro.2020.04.008

[21] Zhao, K.: Acute myelitis after SARS-CoV-2 infection: a case report. https://www.medrxiv. org/content/10.1101/2020.03.16.2003510 $5 \mathrm{v} 2$.full-text

[22] Mao, L.: Neurological manifestations of hospitalized patients with COVID-19 in Wuhan, China: a retrospective case series study. https://jamanetwork.com/journals/ja maneurology/fullarticle/2764549

[23] Gardner, P. J.: Psychological impact on SARS survivors, 123-35. https://psycnet.apa.org/ fulltext/2014-43048-001.html

[24] Lee, S. H.: Depression as a mediator of chronic fatigue and post-traumatic stress symptoms in middle East respiratory syndrome survivors, 59-64. https://www.ncbi.nlm.nih. gov/pmc/articles/PMC6354037/

[25] Hui, D. S.: Impact of severe acute respiratory syndrome (SARS) on pulmonary function, functional capacity and quality of life in a cohort of survivors, 401-409. https://doi. org/10.1136/thx.2004.030205

[26] Caterisano, A.: CSCCa and NSCA joint consensus guidelines for transition periods: safe return to training following inactivity, 1-23. https://doi.org/10.1519/SSC. 0000000000000477

[27] So, R.C.H.: Severe acute respiratory syndrome and sport: facts and fallacies, 1023-33 https://link.springer.com/article/10.2165\% 2F00007256-200434150-00002

[28] Zhu, W.: Should and how can, exercise be done during a coronavirus outbreak? 105-7. 
https://www.ncbi.nlm.nih.gov/pmc/articles/ PMC7031769/

[29] Luzi, L.: Influenza and obesity: its odd relationship and the lessons for COVID-19 pandemic. https://link.springer.com/article/ 10.1007\%2Fs00592-020-01522-8

[30] Hamer, M.: Lifestyle risk factors for cardiovascular disease in relation to COVID-19 hospitalization, 184-7 https://www.ncbi. nlm.nih.gov/pmc/articles/PMC7273266/

[31] Nieman, D. C,: Coronavirus Disease-2019: a tocsin to our aging, unfit, corpulent, and immunodeficient society. https://www.ncbi. nlm.nih.gov/pmc/articles/PMC7205734/

[32] Ignaszewski, M.: The Science of Exercise Prescription: Martti Karvonen and his contributions. https://bcmj.org/articles/scienceexercise-prescription-martti-karvonen-andhis-contributions

\section{Col. Z. Eleki PhD}

\section{Effect of Covid-19 virus infection on physical activity from the moderate to vigorous training}

The pandemic caused by the Covid-19 virus is a major challenge in all walks of life around the world. At the time of writing, the number of confirmed infections exceeded 142 million in the world and 750 thousand in Hungary. Considering that the number of infected depends on the number of tests performed, it is likely that the real numbers are even higher.

As the number of healers increases, we get an increasingly accurate picture of the fact that not all patients end up suffering during the acute phase of the infection, as many organ systems may experience prolonged symptoms, lasting several months, suggesting that the body has not regained its strength. The phenomenon called Long-Covid Syndrome (LCS) most commonly affects the cardiovascular system, respiration, musculoskeletal system, and digestive system.
In addition, depending on the severity we can experience physical deconditioning. The LCS primarily affects those organ systems that are also exposed to exercise during sports activities. If these organ systems are put under a greater strain before they regain their health, it can easily lead to malaise and even permanent damage to health.

The soldiers of the Hungarian Armed Forces also suffer from the infection in large numbers, so the risks related to LCS are also expected to affect the staff. In the case of soldiers, the issue of physical fitness is emphasized, which is confirmed by the mandatory physical assessment repeated annually, therefore it is important for both the individual and the commander that the recovered people regain their condition as soon as possible. However, much depends on the correct dosage of physical exertion, accurate timing and sufficient phasing to avoid premature overload.

Sports and the everyday physical activity help maintain resistance to disease. Considering that the biggest risk factors for Covid-19 infection are obesity, high blood pressure and diabetes, the importance of returning to daily exercise should not be an issue.

The aim of this publication is to map the symptoms expected in LCS and taking these into account, how to ensure a gradual and safe return to predisease activity levels.

Key-words: Long-Covid, pandemic, rehabilitation, physical training, physical conditioning

Dr. Eleki Zoltán ezds., $P h D$ 2000 Szentendre, Dózsa Gy. út 11. 